\title{
Pembangunan Dashboard Beasiswa dan Pinjaman Program Studi Informatika UKDW
}

\author{
Agustinus Rendi Walewowan ${ }^{1}$, Willy Sudiarto Raharjo ${ }^{2}$, Gloria Virginia ${ }^{3}$ \\ ${ }^{1,2,3}$ Departemen Informatika, Universitas Kristen Duta Wacana, Yogyakarta, Indonesia \\ agustinus.rendi@ti.ukdw.ac.id \\ willysr@ti.ukdw.ac.id \\ virginia@staff.ukdw.ac.id
}

Diterima 10 Januari 2020

Disetujui 17 Juni 2020

\begin{abstract}
The head of the study program (kaprodi) has many tasks and responsibilities that must be done in academic activities. One of the tasks of the head of the study program is a report on the entire implementation of activities in a study program. For that, we need a system that can be used for daily operational activities and provide reports. A dashboard is an information panel display that is used in an organization to consider a problem making it easier for someone to make a decision. This study made a dashboard scholarship and loan design using the prototyping method. Prototyping is a software development method, which consists of a physical work system model and an initial version of the system. The results of the average task success testing in both iterations, namely 96.66 so that the system built can be said to be quite effective in displaying scholarship and loan information and easy to learn. Interface design evaluations were carried out using the System Usability Scale (SUS) for 5 respondents in each iteration and resulted in a SUS score of 75.2 in iteration $I$ and 76.6 in iteration II. Based on these results, the average SUS score for both iterations is 75.9. Thus, the system interface is stated to be good with a grade scale of $\mathrm{C}$ value, adjective rating of Good value, and acceptability ranges are acceptable.
\end{abstract}

Index Terms-Dashboard, Prototyping, System Usability Scale, Task Success

\section{PENDAHULUAN}

Fakultas Teknologi Informasi Universitas Kristen Duta Wacana (UKDW) Yogyakarta merupakan salah satu fakultas favorit sehingga memiliki jumlah mahasiswa yang banyak. Dengan jumlah mahasiswa yang banyak, data yang disimpan juga semakin banyak sehingga menghasilkan informasi yang beragam, diantaranya adalah informasi mengenai peminjaman dan beasiswa.

Ketua program studi (kaprodi) memiliki peranan penting di sebuah program studi (prodi). Dalam kegiatan akademik kaprodi memiliki banyak tugas dan tanggung jawab yang harus dilaksanakan. Salah satu tugas dari seorang kaprodi adalah melaporkan seluruh pelaksanaan kegiatan di suatu prodi. Untuk itu, diperlukan suatu sistem yang dapat digunakan untuk memantau kegiatan operasional sehari-hari dan memberikan laporan, khususnya kegiatan mahasiswa mengenai pinjaman dan penerimaan beasiswa dalam lingkungan program studi (prodi) informatika, sekaligus membantu proses pengambilan keputusan strategis.

Dashboard adalah sebuah tampilan panel informasi yang digunakan dalam suatu organisasi untuk mengevaluasi suatu masalah sehingga memudahkan seseorang untuk mengambil keputusan. Tactical dashboard adalah sebuah tampilan dashboard yang menggunakan data pada kondisi sebelumnya untuk mengidentifikasi tren sehingga dapat membantu seseorang untuk menganalisis dan membuat keputusan kedepannya.

Penelitian ini bertujuan melakukan perancangan sebuah dashboard beasiswa dan pinjaman dengan menggunakan metode prototyping. Prototyping adalah metode pengembangan perangkat lunak, yang berupa model fisik kerja sistem dan berfungsi sebagai versi awal dari sistem. [1]. Dengan adanya dashboard tersebut, diharapkan dapat membantu kaprodi dalam menganalisis aktivitas peminjaman dan beasiswa mahasiswa prodi informatika.

\section{LANDASAN TEORI}

\section{A. Dashboard}

Menurut Few dalam [2], Dashboard dapat diartikan sebagai information dashboard yaitu tampilan visual dari informasi penting yang diperlukan untuk mencapai satu atau beberapa tujuan dengan mengkonsolidasikan dan mengatur informasi dalam satu layar (single screen), sehingga kinerja organisasi dapat dimonitor secara sekilas.

Ada beberapa macam tipe dashboard, menurut Rasmussen, Bansal, dan Chen dalam [3], yaitu:

1. Strategic dashboard digunakan untuk mendukung manajemen level strategis memberikan informasi dalam membuat keputusan bisnis, memprediksi peluang, dan memberikan arahan pencapaian tujuan strategis. 
2. Analytical dashboard berfokus pada proses analisis untuk menentukan penyebab dari suatu kondisi atau kejadian tertentu.

3. Operational dashboard yang berfungsi sebagai pendukung monitoring dari aktifitas proses bisnis yang spesifik. Fokus pada monitoring aktifitas dan kejadian yang tidak berubah secara konstan.

\section{B. Tactical Dashboard}

Tactical dashboard merupakan dashboard yang disiapkan untuk tujuan yang lebih rinci, biasanya digunakan untuk melacak tren dan dalam kaitannya dengan tujuan dan inisiatif perusahaan [4].

\section{Prototyping}

Prototyping merupakan metode pengembangan perangkat lunak, yang berupa model fisik kerja sistem dan berfungsi sebagai versi awal dari sistem. Metode prototyping akan menghasilkan prototype sistem sebagai perantara pengembang dan pengguna agar dapat berinteraksi dalam proses kegiatan pengembangan sistem informasi [1].

\section{Requirement gathering}

Tahap ini customer dan developer bersamasama menentukan tujuan seluruh perangkat lunak, mengidentifikasikan semua kebutuhan, dan garis besar sistem yang akan dibangun.

\section{Quick design}

Tahap ini berfokus pada representasi semua aspek perangkat lunak yang terlihat oleh user seperti perancangan antarmuka dalam membentuk mock up atau desain tampilan sistem disesuaikan dengan kebutuhan user.

\section{Building of the prototype}

Tahap ini dibuat prototype yang mewakili sistem yang akan dibangun.

\section{Evaluation and refinement requirement}

Tahap ini evaluasi ini dilakukan oleh customer apakah prototype yang dibangun sudah sesuai dengan keinginann customer.

\section{The Advantages of Prototyping}

Prototyping method memiliki beberapa kelebihan [5], yaitu :

1. Komunikasi yang baik antara developer dan customer.

2. Developer dapat bekerja lebih baik dalam menentukan kebutuhan customer.

3. Customer berperan aktif dalam pengembangan sistem.
4. Aplikasi menjadi lebih mudah karena user tahu apa yang diharapkan.

\section{E. Usability Testing}

Usability adalah atribut kualitas yang menilai seberapa mudah antarmuka pengguna digunakan. Kata "usability" juga merujuk pada metode untuk meningkatkan kemudahan penggunaan selama proses desain [6]. Usability didefinisikan menjadi 5 komponen, yaitu:

- Learnability: seberapa mudah bagi pengguna untuk menyelesaikan tugas-tugas dasar saat pertama kali mereka menghadapi desain?

- Efficiency: seberapa cepat mereka dapat melakukan tugas setelah pengguna mempelajari desain?

- Memorability: Ketika pengguna kembali ke desain setelah periode tidak menggunakannya, seberapa mudah mereka dapat membangun kembali kemahiran?

- Errors: Berapa banyak kesalahan yang dilakukan pengguna, seberapa parah kesalahan ini, dan seberapa mudah mereka pulih dari kesalahan?

- Satisfaction: Seberapa menyenangkan menggunakan desain?

\section{F. Hukum Gestalt}

Prinsip atau hukum Gestalt adalah aturan yang menggambarkan bagaimana mata manusia memandang elemen visual. Prinsip-prinsip ini bertujuan untuk menunjukkan bagaimana adegan kompleks dapat direduksi menjadi bentuk yang lebih sederhana. Hal tersebut bertujuan untuk menjelaskan bagaimana mata memandang bentuk sebagai satu kesatuan, bentuk daripada elemen-elemen sederhana yang terlibat [7].

Kecenderungan pengorganisasian tata letak secara keseluruhan ada pada prinsip-prinsip gestalt tentang pengelompokan (Gestalt Priciples of Grouping) yang berpijak pada kecenderungan manusia untuk mengorganisasi stimuli yang terpisah menjadi pengelompokan yang berdasar pada proximity (kedekatan), similarity (kemiripan), closure (ketertutupan), continuity (kesinambungan), dan symmetry (simetris) [8].

1. Proximity (kedekatan), bentuk-bentuk sederhana yang disusun bersama dapat menciptakan gambar yang lebih kompleks.

2. Similarity (kemiripan), mata manusia cenderung membangun hubungan antara elemen-elemen serupa dalam suatu desain. Kesamaan dapat dicapai dengan 
menggunakan elemen-elemen dasar seperti bentuk, warna, dan ukuran.

3. Closure (ketertutupan) mata manusia cenderung melihat suatu bentuk secara utuh atau melihatnya secara keseluruhan.

4. Continuity (kesinambungan) mata manusia mengikuti jalur, garis, dan kurva desain, dan lebih suka melihat aliran elemen visual yang berkelanjutan daripada objek yang terpisah.

5. Symmetry (simetris) desain yang dibangun harus seimbang dan lengkap. Jika tidak, pengguna akan menghabiskan waktu dan upaya mencoba memahami gambar keseluruhan.

\section{G. Reporting}

Reporting adalah salah satu fungsi manajemen berupa penyampaian perkembangan atau hasil kegiatan mengenai segala hal yang berkaitan dengan tugas dan fungsi-fungsi kepada pejabat yang lebih tinggi. [9].

Reporting sering digunakan oleh suatu organisasi untuk membantu dalam menganalisis tren dan perkembangan sehingga dapat menentukan keputusan yang strategis.

\section{H. Success Rate}

Success rate adalah persentase dari task yang berhasil dikerjakan oleh pengguna. Success rate digunakan untuk mengetahui tingkat kemudahan pengguna dalam menyelesaikan tugas yang diberikan [10].

Berikut rumus yang digunakan untuk menghitung success rate:

$$
\left[\frac{\text { Success Task }+ \text { (Partial Success } x 0,5)}{\text { Total Task }} \times 100 \%\right]
$$

Penilain yang diberikan berdasarkan aturan yaitu, setiap task yang berhasil akan diberi nilai 1 dan berhasil sebagian diberi nilai 0,5 , sedangkan jika task tersebut gagal akan diberi nilai 0 .

\section{System Usability Scale}

System Usability Scale (SUS) adalah metode pengujian yang menyediakan alat ukur yang "quick and dirty". SUS terdiri dari 10 kuesioner dengan lima pilihan respons untuk responden, dari "sangat tidak setuju" hingga "sangat setuju" [11].

\section{J. Key Performance Indicator (KPI)}

Menurut Banerjee dan Buoti, [12]. Key Performance Indicator merupakan ukuran berskala dan kuantitatif yang digunakan untuk mengevaluasi kinerja organisasi dalam tujuan mencapai target organisasi. KPI juga digunakan untuk menentukan objektif yang terukur, melihat tren, dan mendukung pengambilan keputusan
Dalam lingkungan perguruan tinggi, KPI sangat berhubungan erat dengan proses bisnis organisasi, dan standar yang ditetapkan Badan Akreditasi Nasional Perguruan Tinggi (BAN-PT). Salah satu contoh KPI adalah profil mahasiswa, dengan menguraikan KPI menjadi beberapa jenis informasi, yaitu jumlah calon mahasiswa baru (ikut seleksi), jumlah mahasiswa baru, dan total mahasiswa [13].

\section{K. Tabel Fakta (Fact Tables)}

Fact Table merupakan tabel yang mengacu pada setiap performa yang dapat diukur (measure). Tabel fakta merupakan primary key dari masing-masing tabel dimensi yang di kumpul menjadi foreign key dalam satu tabel. Hampir setiap tabel fakta biasanya berisi nilai numeric. Namun, tidak semua nilai numeric termasuk dalam tabel fakta. Misalnya, ukuran luas fasilitas. Ukuran luas fasilitas tidak termasuk tabel fakta karena merupakan sebuah deskripsi statis yang harus disimpan dalam dimensi fasilitas [14].

\section{Tabel Dimensi (Dimension Tables)}

Dimension Table adalah tabel dalam dimensional model dengan sebuah primary key dan kolom atributatribut yang deskriptif. Atribut pada tabel dimensi memiliki dua tujuan utama yaitu filtering dan labelling. Tabel dimensi berisi konteks tekstual yang terkait dengan kegiatan pengukuran proses bisnis, menjelaskan "siapa, apa, dimana, kapan, bagaimana, dan mengapa" berkaitan dengan kegiatan tersebut [14].

\section{PERANCANGAN Sistem}

A. Key Performance Indicator (KPI)

Tabel 1. Key Performance Indicator (KPI)

\begin{tabular}{|c|c|c|c|}
\hline No. & Nama & Fungsi & Satuan \\
\hline 1. & $\begin{array}{l}\text { Persentase } \\
\text { mahasiswa yang } \\
\text { melunasi / } \\
\text { membayar } \\
\text { pinjaman Biro } 3 .\end{array}$ & $\begin{array}{l}\text { Melihat } \\
\text { persentase } \\
\text { mahasiswa yang } \\
\text { telah melunasi } \\
\text { pinjaman di biro } \\
3 \text { setiap semester }\end{array}$ & $\begin{array}{l}\text { Jumlah } \\
\text { mahasiswa }\end{array}$ \\
\hline 2. & $\begin{array}{l}\text { Persentase } \\
\text { mahasiswa yang } \\
\text { pinjam ke biro } 3 \text { di } \\
\text { setiap angkatan. }\end{array}$ & $\begin{array}{l}\text { Melihat } \\
\text { persentase } \\
\text { mahasiswa yang } \\
\text { melakukan } \\
\text { peminjaman ke } \\
\text { biro } 3\end{array}$ & $\begin{array}{l}\text { Jumlah } \\
\text { mahasiswa }\end{array}$ \\
\hline 3. & $\begin{array}{l}\text { Persentase } \\
\text { mahasiswa prodi } \\
\text { informatika yang } \\
\text { mendapatkan } \\
\text { beasiswa (Internal } \\
\text { UKDW / Diluar } \\
\text { UKDW. }\end{array}$ & $\begin{array}{l}\text { Melihat } \\
\text { persentase } \\
\text { mahasiswa yang } \\
\text { mendapatkan } \\
\text { beasiswa internal } \\
\text { maupun diluar } \\
\text { UKDW. }\end{array}$ & $\begin{array}{l}\text { Jumlah } \\
\text { mahasiswa }\end{array}$ \\
\hline 4. & $\begin{array}{l}\text { Rata-rata jumlah } \\
\text { mahasiswa di setiap } \\
\text { angkatan yang } \\
\text { mendapatkan } \\
\text { beasiswa. }\end{array}$ & $\begin{array}{l}\text { Menghitung rata - } \\
\text { rata jumlah } \\
\text { mahasiswa } \\
\text { penerima } \\
\text { beasiswa setiap } \\
\text { angkatan. }\end{array}$ & $\begin{array}{l}\text { Jumlah } \\
\text { mahasiswa }\end{array}$ \\
\hline 5. & $\begin{array}{l}\text { Rata-rata jumlah } \\
\text { dana beasiswa di } \\
\text { setiap angkatan. }\end{array}$ & $\begin{array}{l}\text { Menghitung rata } \\
\text { - rata jumlah } \\
\text { dana beasiswa }\end{array}$ & Rupiah \\
\hline
\end{tabular}


\begin{tabular}{|l|l|l|l|}
\hline & & setiap angkatan. & \\
\hline
\end{tabular}

Tabel 1 merupakan daftar Key Performance Indicator (KPI) beasiswa dan pinjaman yang akan digunakan dalam sistem. KPI diperlukan agar pengguna dapat mengetahui porforma mengenai data pinjaman dan beasiswa berada dalam keadaan buruk, normal, atau baik.

\section{B. Perancangan Unit}

Perancangan sistem ini memiliki beberapa fungsi utama sebagai berikut:

1. Pencarian Data

User dapat melakukan pencarian terhadap suatu data. Pencarian data yang dimaksud adalah pencarian mengenai data mahasiswa seperti nama, angkatan, dan nim.

2. Detail Informasi

User dapat melihat detail informasi mengenai data yang ditampilkan dalam bentuk chart.

\section{Reporting}

Fungsi ini menampilkan data secara keseluruhan dalam bentuk tabel sehingga mudah diolah oleh user.

\section{Data Schema}

Schema data yang digunakan dalam penelitian ini mengacu pada data warehouse prodi informatika.

Tabel 2. Struktur tabel dim_beasiswa

\begin{tabular}{|c|c|}
\hline Nama Kolom & Tipe Data \\
\hline id_beasiswa & big integer \\
\hline id_wilayah & big integer \\
\hline nama_beasiswa & char \\
\hline jumlah_beasiswa & decimal \\
\hline
\end{tabular}

Tabel 3. Struktur tabel dim_wilayah

\begin{tabular}{|c|c|}
\hline Nama Kolom & Tipe Data \\
\hline id_wilayah & big integer \\
\hline level_wilayah & char \\
\hline
\end{tabular}

Tabel 2 merupakan tabel dim_beasiswa yang akan menampung data penerima beasiswa. Sedangkan tabel 3 merupakan tabel dim_wilayah yang akan menampung data asal beasiswa berdasarkan level wilayah. Level wilayah dibagi menjadi 4 yaitu internal, regional, nasional, dan internasional.

Tabel 4. Struktur tabel dim_mahasiswa

\begin{tabular}{|c|c|}
\hline Nama Kolom & Tipe Data \\
\hline id_mahasiswa & big integer \\
\hline id_prodi & big integer \\
\hline nim & char \\
\hline
\end{tabular}

\begin{tabular}{|c|c|}
\hline tahun_angkatan & char \\
\hline nama & char \\
\hline jenis_kelamin & char \\
\hline tanggal_lahir & date \\
\hline tempat_lahir & char \\
\hline agama & char \\
\hline id_kodepos_mahasiswa & char \\
\hline alamat & char \\
\hline slta_smk & char \\
\hline jurusan_slta_smk & char \\
\hline id_kodepos_slta_smk & char \\
\hline id_tanggal_do & int \\
\hline id_tanggal_undur_diri & int \\
\hline id_tanggal_registrasi & int \\
\hline status & char \\
\hline ipk_terakhir & float \\
\hline
\end{tabular}

Tabel 4 merupakan tabel dim_mahasiswa yang akan menampung semua data tentang mahasiswa.

Tabel 5. Struktur tabel dim_jenis_pembayaran

\begin{tabular}{|c|c|}
\hline Nama Kolom & Tipe Data \\
\hline id_jenis_pembayaran & big integer \\
\hline id_beasiswa & big integer \\
\hline jumlah_pembayaran_mandiri & decimal \\
\hline jumlah_pembayaran_beasiswa & decimal \\
\hline jumlah_pembayaran_pinjaman & decimal \\
\hline
\end{tabular}

Tabel 5 merupakan tabel dim_jenis_pembayaran yang akan menampung data tentang pembayaran. Data pembayaran yang dimaksud adalah data pembayaran mandiri, beasiswa, dan pinjaman.

Tabel 6. Struktur tabel dim_date

\begin{tabular}{|c|c|}
\hline Nama Kolom & Tipe Data \\
\hline id_date & big integer \\
\hline tanggal & date \\
\hline hari_dalam_tahun & int \\
\hline hari_dalam_bulan & int \\
\hline hari_dalam_minggu & int \\
\hline nama_hari & char \\
\hline bulan & int \\
\hline nama_bulan & char \\
\hline kuartal & int \\
\hline tahun & char \\
\hline tahun_ajaran & char \\
\hline semester & int \\
\hline semester_yudisium & int \\
\hline
\end{tabular}

Tabel 6 merupakan tabel dim_date yang akan menampung semua yang berhubungan dengan tanggal, tahun, bulan, dan hari. 
Tabel 7. Struktur tabel fact_pembayaran registrasi

\begin{tabular}{|c|c|}
\hline Nama Kolom & Tipe Data \\
\hline id_pembayaran_registrasi & big integer \\
\hline id_mahasiswa & big integer \\
\hline id_date & big integer \\
\hline id_jenis_pembayaran & big integer \\
\hline jumlah & decimal \\
\hline
\end{tabular}

Tabel 7

merupakan

tabel fact_pembayaran_registrasi yang akan menampung semua primary key dari masing-masing tabel dimensi sehingga menjadi foreign key.

Tabel 8. Struktur tabel dim_prodi

\begin{tabular}{|c|c|}
\hline Nama Kolom & Tipe Data \\
\hline id_prodi & big integer \\
\hline kode_prodi & varchar \\
\hline kode_fakultas & varchar \\
\hline nama_fakultas & varchar \\
\hline nama_prodi & varchar \\
\hline nama_universitas & varchar \\
\hline
\end{tabular}

Tabel 8 merupakan tabel dim_prodi yang menampung semua data mengenai program studi dan fakultas.

Tabel 9. Struktur tabel dim_kodepos

\begin{tabular}{|c|c|}
\hline Nama Kolom & Tipe Data \\
\hline id_kodepos & big integer \\
\hline kodepos & varchar \\
\hline kabupaten_kota & varchar \\
\hline provinsi & varchar \\
\hline provinsi_en & varchar \\
\hline
\end{tabular}

Tabel 9 merupakan tabel dim_kodepos yang menampung data mengenai kode pos, kabupaten dan provinsi. kedua tabel tersebut akan membantu menampung data yang diperlukan oleh tabel mahasiswa.

Tabel 10. Struktur tabel fact_transaksi_lunas

\begin{tabular}{|c|c|}
\hline Nama Kolom & Tipe Data \\
\hline id_transaksi_lunas & big integer \\
\hline id_pembayaran_registrasi & big integer \\
\hline id_date & big integer \\
\hline jumlah_pembayaran_cicilan & decimal \\
\hline
\end{tabular}

Tabel 10 merupakan tabel fact_transaksi_lunas yang akan menampung primary key dari tabel fact_pembayaran_registrasi dan dim_date. ID_pembayaran_registrasi pada tabel ini digunakan sebagai penampung ID yang sudah melalukan pembayaran pinjaman, sedangkan id_date digunakan untuk menampung tanggal ID tersebut membayar pinjaman.

\section{IMPLEMENTASI DAN ANALISIS}

\section{A. Implementasi Dashboard}

\section{A.1 Halaman Login}

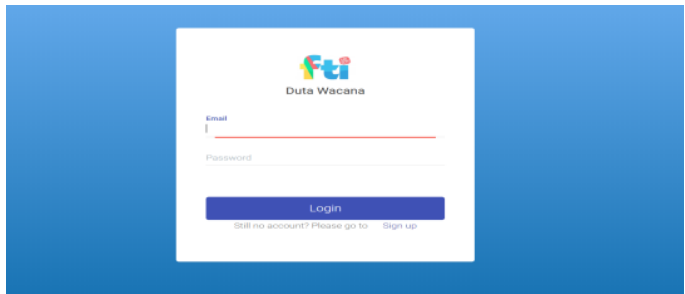

Gambar 1. Halaman login

Gambar 1 merupakan tampilan halaman login dari dashboard yang telah dibangun. Halaman login adalah halaman awal yang ditampilkan pada saat membuka sistem. Agar dapat masuk ke dalam sistem user harus mengisi email dan password yang telah terdaftar sebagai bagian dari proses autentikasi.

\section{A.2 Halaman Utama Dashboard Mahasiswa}

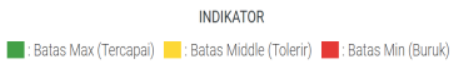

Pilih Tahun Periode: 2019 Gasal ,

Gambar 2. Indikator dan filter tahun periode

Gambar 2 merupakan tampilan indikator dan tahun periode pada halaman utama dashboard.

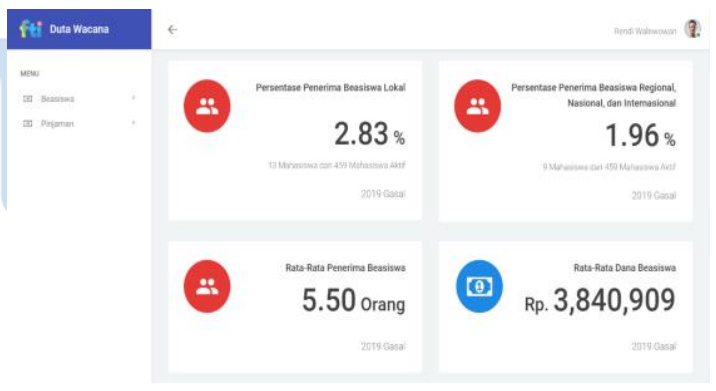

Gambar 3. Tampilan utama dashboard beasiswa

Gambar 3 merupakan tampilan utama dari dashboard. Setelah user melakukan autentikasi, user akan diarahkan ke halaman ini. Halaman utama dashboard akan menampilkan informasi sesuai dengan periode waktu yang dipilih. Selain itu, halaman ini terdapat icon berwarna yang menggambarkan kondisi sesuai dengan periode waktu yang dipilih. Warna - warna tersebut sesuai dengan warna indikator yang dapat dilihat pada Gambar 2 . 
A.3 Halaman Beasiswa Lokal

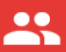

Persentase Penerima Beasiswa Loka

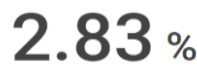

13 Mahasiswa dari 459 Mahasiswa Aktif

2019 Gasal

Gambar 4. KPI persentase penerima beasiswa lokal

Gambar 4 merupakan tampilan dari KPI persentase penerima beasiswa lokal. Ketika user melakukan click pada KPI tersebut, maka user akan diarahkan ke halaman beasiswa lokal seperti pada Gambar 5.
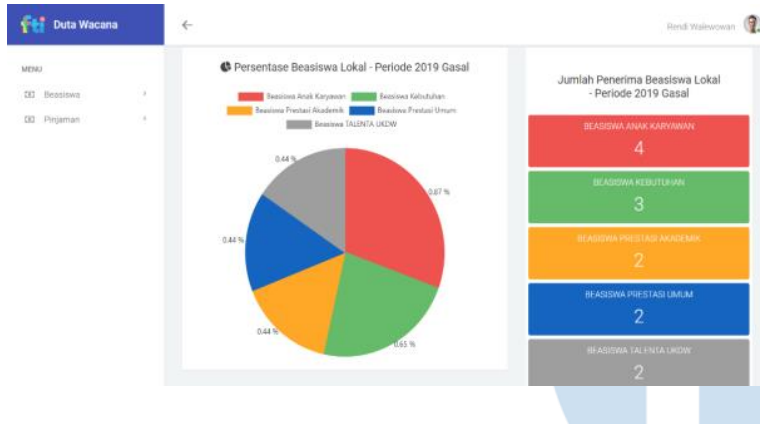

Gambar 5. Halaman beasiswa lokal

Halaman beasiswa lokal menampilkan persentase beasiswa dalam bentuk pie chart serta jumlah penerima beasiswa yang dikategorikan berdasarkan nama beasiswa.

A.4 Halaman Beasiswa Regional, Nasional, Internasional

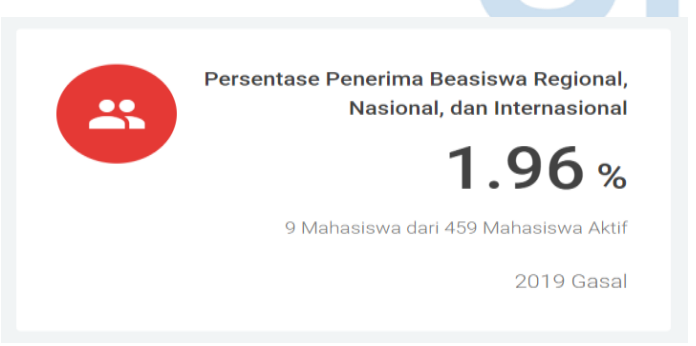

Gambar 6. KPI persentase beasiswa regional, nasional, internasional

Gambar 6 merupakan tampilan dari KPI persentase penerima beasiswa regional, nasional dan internasional. Ketika user melakukan click pada KPI tersebut, maka user akan diarahkan ke halaman beasiswa regional, nasional dan internasional seperti pada Gambar 7.
A.5 Halaman Rata-rata Penerima Beasiswa

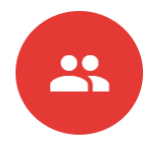

Rata-Rata Penerima Beasiswa

\subsection{0 orang}

2019 Gasal

Gambar 7. KPI rata-rata penerima beasiswa

Gambar 8 merupakan tampilan dari KPI rata-rata penerima beasiswa pada periode waktu tertentu.

\section{2 orang \\ Rp. $84,500,000$ \\ Total Penerima Beasiswa \\ Total Dana Beasiswa}

Gambar 8. Total penerima dan total dana beasiswa

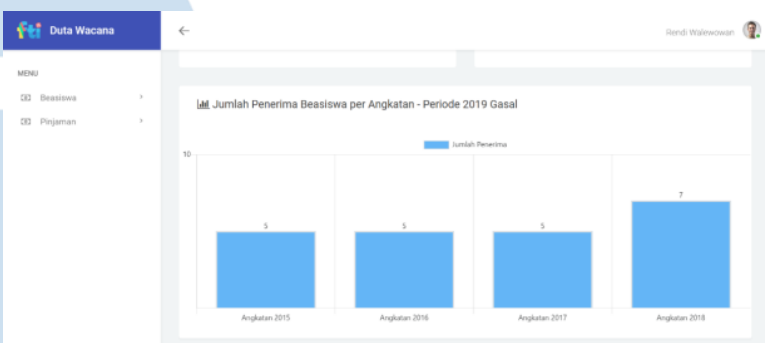

Gambar 9. Bar chart jumlah penerima beasiswa

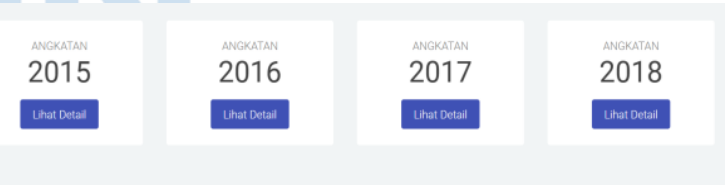

Gambar 10. Card tahun angkatan

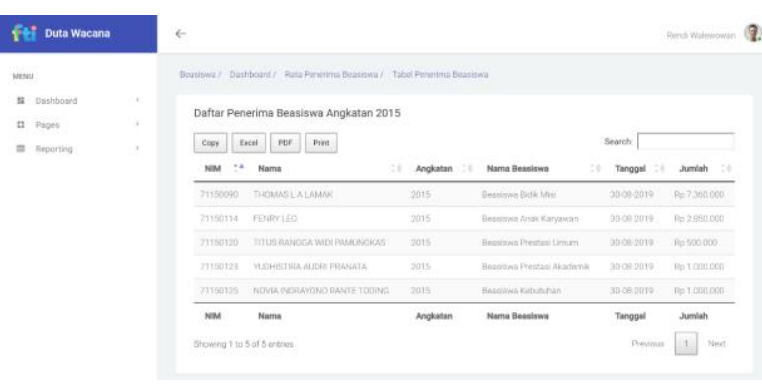

Gambar 11. Halaman daftar penerima beasiswa per angkatan 
Gambar 9 sampai 12 merupakan tampilan halaman rata-rata penerima beasiswa. Halaman ini menampilkan total penerima dan total dana beasiswa pada periode waktu tertentu seperti pada Gambar 9. Gambar 10 menampilkan jumlah penerima beasiswa per angkatan dalam bentuk bar chart.

Gambar 11 merupakan card yang menampilkan tahun angkatan sesuai dengan yang ditampilkan pada bar chart. Pada card tersebut terdapat tombol "Lihat Detail" yang akan mengarah ke halaman daftar penerima beasiswa per angkatan seperti pada Gambar 12.

\section{A.6 Halaman Rata-rata Dana Beasiswa}

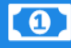
Rp. $3,840,909$

Gambar 12. KPI rata-rata dana beasiswa

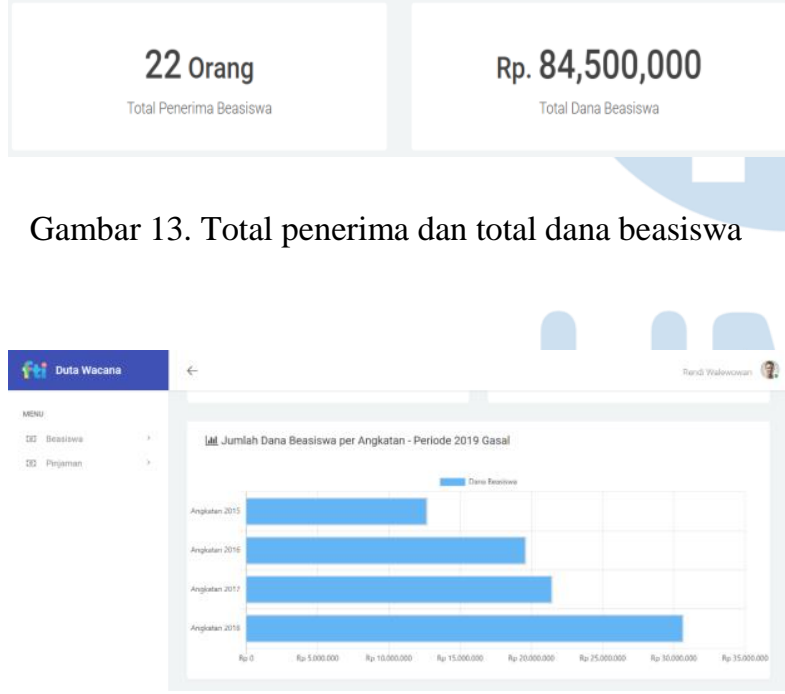

Gambar 14. Horizontal bar chart jumlah dana beasiswa

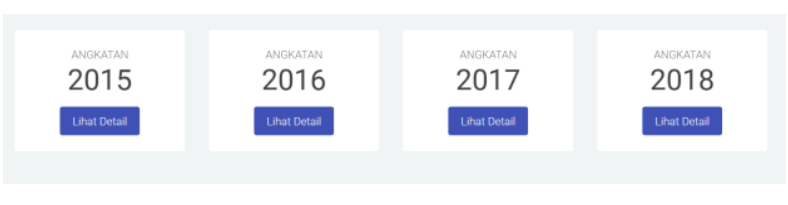

Gambar 15. Card tahun angkatan

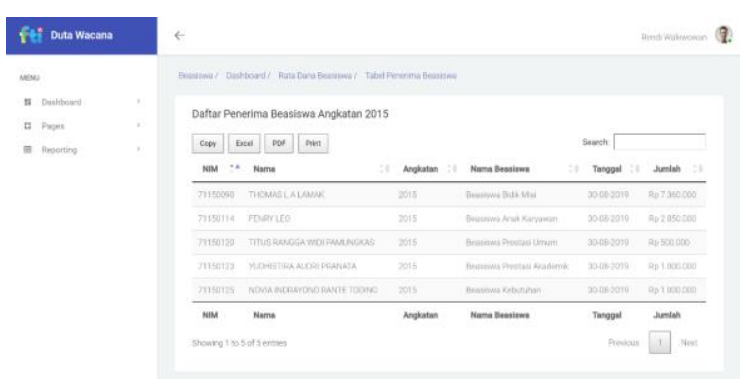

Gambar 16. Halaman daftar penerima beasiswa per angkatan

Gambar 13 sampai 17 merupakan tampilan halaman rata-rata dana beasiswa. Halaman ini tidak jauh berbeda dengan halaman rata-rata penerima beasiswa yang tetap menampilkan total penerima dan total dana beasiswa pada periode waktu tertentu seperti pada Gambar 14. Perbedaannya terletak hanya pada pemilihan chart seperti pada Gambar 15 yang menampilkan jumlah dana beasiswa per angkatan dalam bentuk horizontal bar chart. Selain itu, Gambar 16 merupakan card yang menampilkan tahun angkatan sesuai dengan yang ditampilkan pada horizontal bar chart yang akan mengarah ke halaman daftar penerima beasiswa per angkatan seperti pada Gambar 17.

\section{A.7 Halaman Reporting Beasiswa}

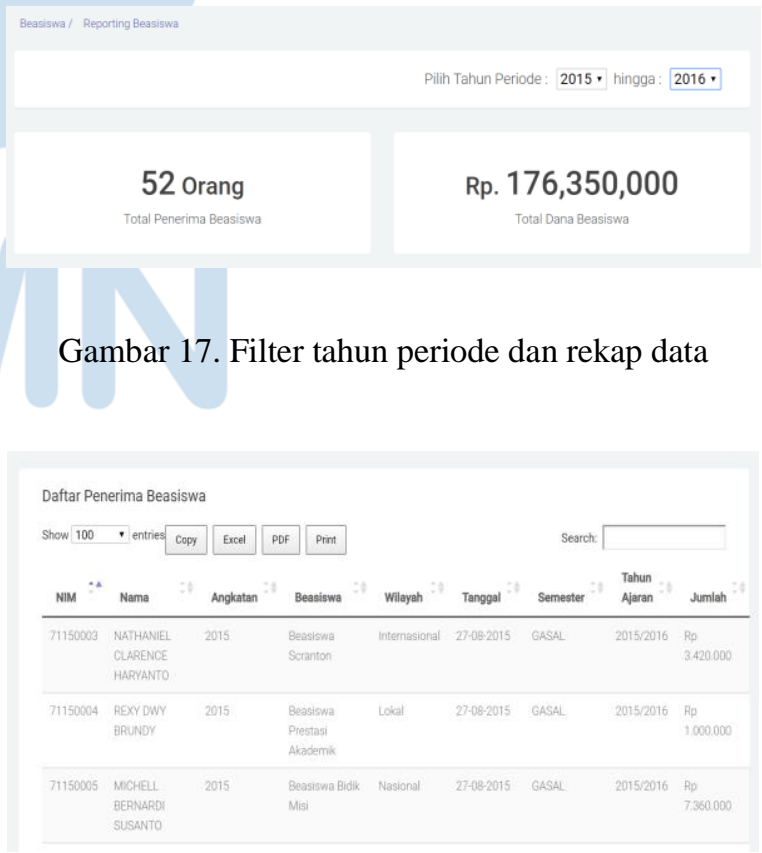

Gambar 18. Tabel reporting beasiswa

Halaman reporting menyediakan dua filter tahun periode yang memungkin user untuk melihat data dalam range waktu tertentu sesuai dengan keinginkan user dan rekap data secara keseluruhan seperti pada gambar 18. Selain itu, terdapat tabel reporting yang menampung data penerima beasiswa yang terdiri dari 
nim, nama, angkatan, nama beasiswa, wilayah, tanggal terima beasiswa, semester, tahun ajaran dan jumlah beasiswa yang diterima seperti yang terlihat pada Gambar 19. Pada halaman reporting terdapat beberapa fitur yang dapat membantu user dalam mengolah data seperti search, export data ke dalam bentuk excel, pdf, print dan copy.

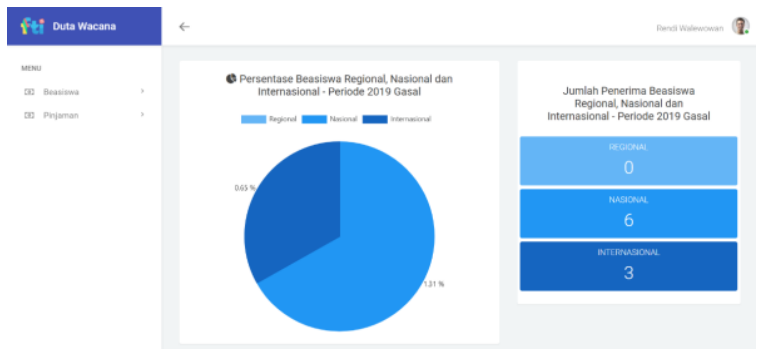

Gambar 19. Halaman beasiswa regional, nasional, internasional

Halaman beasiswa regional, nasional dan internasional menampilkan persentase beasiswa dalam bentuk pie chart serta jumlah penerima beasiswa yang dikategorikan berdasarkan wilayah beasiswa.

\section{A.8 Halaman Utama Dashboard Pinjaman}

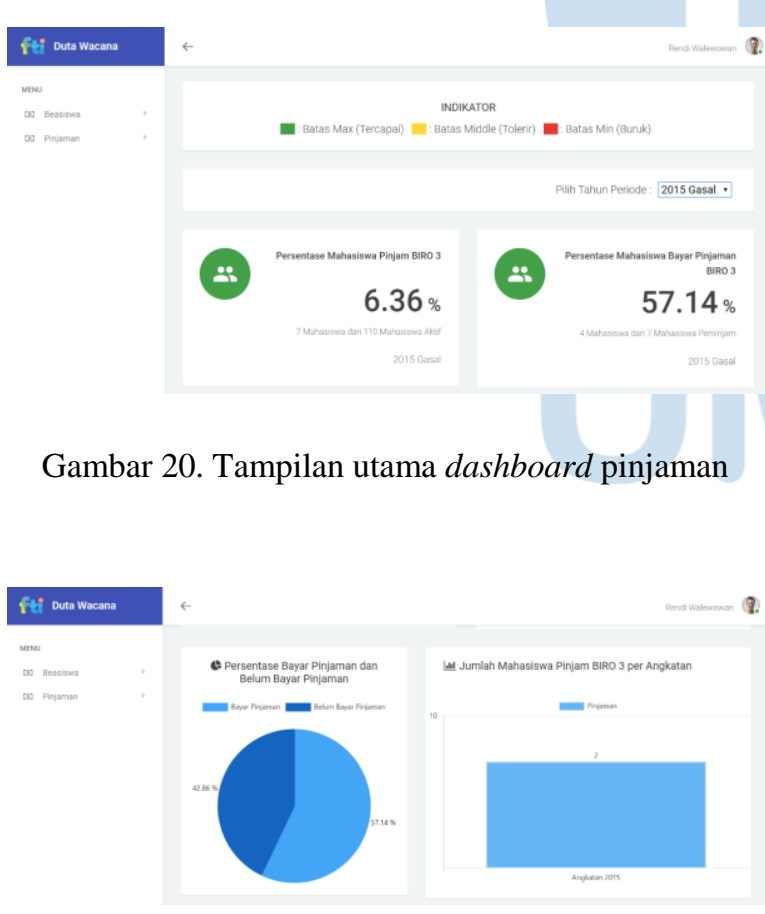

Gambar 21. Pie chart dan bar chart halaman utama dashboard pinjaman

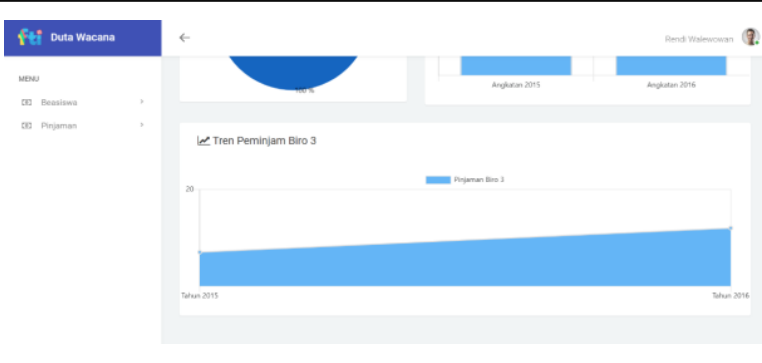

Gambar 22. Line chart halaman utam dashboard pinjaman

Gambar 20 sampai Gambar 22 merupakan tampilan utama dari dashboard pinjaman. Halaman utama dashboard pinjaman akan menampilkan informasi sesuai dengan periode waktu yang dipilih dan tren pinjaman per tahun dalam bentuk line chart. Selain itu, halaman ini terdapat icon berwarna yang menggambarkan kondisi sesuai dengan periode waktu yang dipilih. Gambar 21 menampilkan persentase bayar pinjaman dan belum bayar pinjaman dalam bentuk pie chart serta jumlah mahasiswa pinjam per angkatan dalam bentuk bar chart.

A.9 Halaman Pinjaman Biro 3

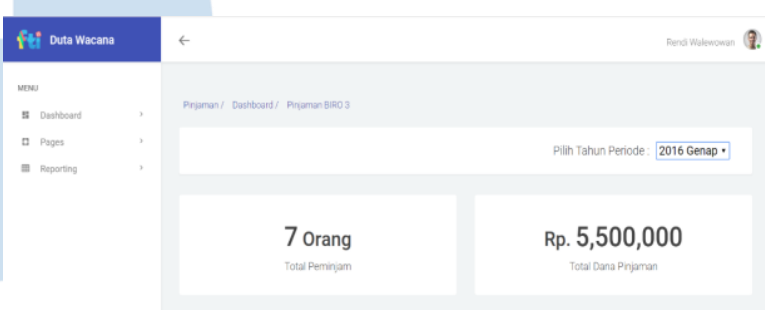

Gambar 23. Filter tahun dan rekap data peminjam

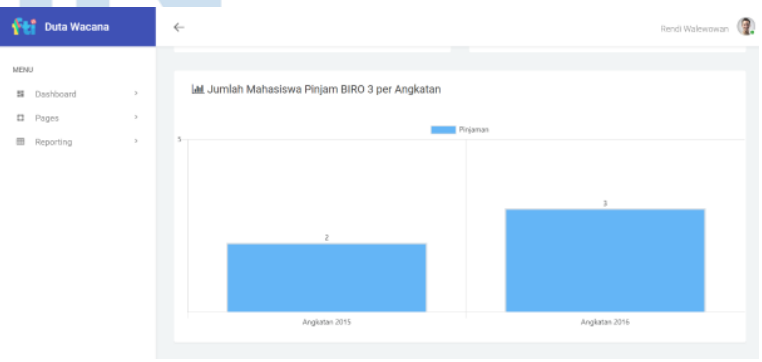

Gambar 24. Bar chart halaman peminjam biro 3 per angkatan 


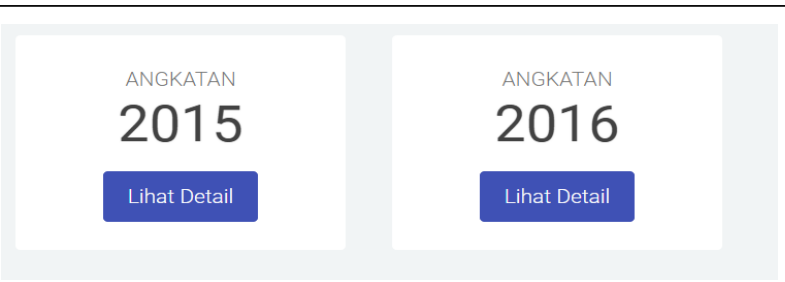

Gambar 25. Card tahun angkatan

Gambar 23 sampai 25 merupakan tampilan halaman pinjaman biro 3. Halaman ini menampilkan informasi total peminjam dan total dana pinjaman pada periode waktu tertentu seperti pada Gambar 22. Halaman ini menampilkan jumlah peminjam per angkatan dalam bentuk bar chart. Gambar 23 sampai 25 merupakan tampilan halaman pinjaman biro 3 . Halaman ini menampilkan informasi total peminjam dan total dana pinjaman pada periode waktu tertentu seperti pada Gambar 22. Halaman ini menampilkan jumlah peminjam per angkatan dalam bentuk bar chart.

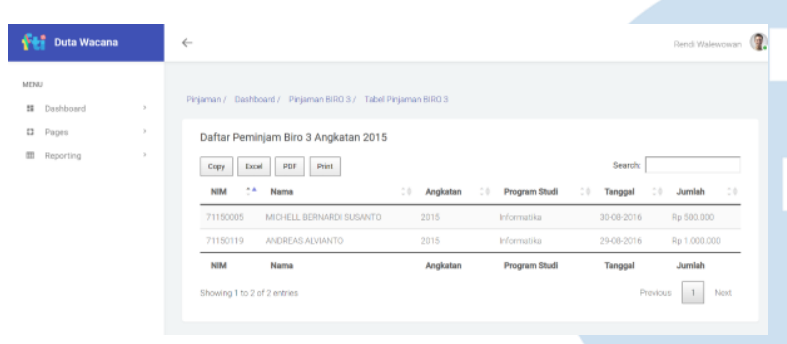

Gambar 26. Halaman daftar pinjaman biro 3 per angkatan

Gambar 25 merupakan card yang menampilkan tahun angkatan sesuai dengan yang ditampilkan pada chart yang akan mengarah ke halaman daftar peminjam per angkatan seperti pada Gambar 26.

A.10 Halaman Pembayaran Pinjaman

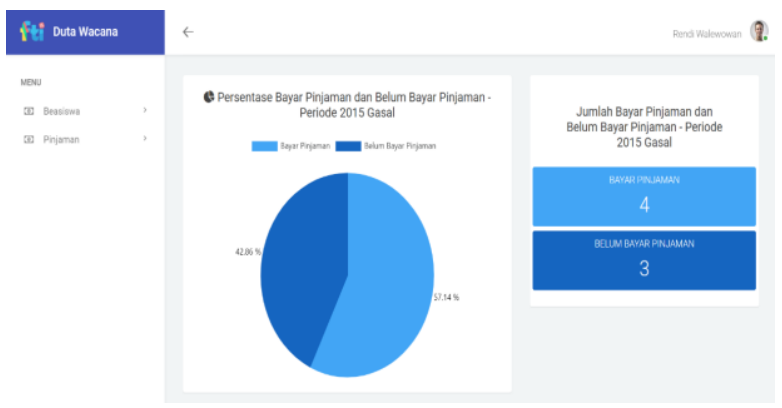

Gambar 27. Halaman pembayaran pinjaman

Gambar 27 merupakan tampilan halaman pembayaran pinjaman. Halaman ini menampilkan informasi jumlah mahasiswa yang telah membayar dan belum membayar pinjaman pada periode waktu tertentu.
User akan diarahkan ke halaman tabel mahasiswa yang belum membayar pinjaman dan yang sudah membayar pinjaman seperti pada Gambar 28 dan Gambar 29 jika melakukan click pada card jumlah bayar pinjaman dan belum bayar pinjaman pada Gambar 27.

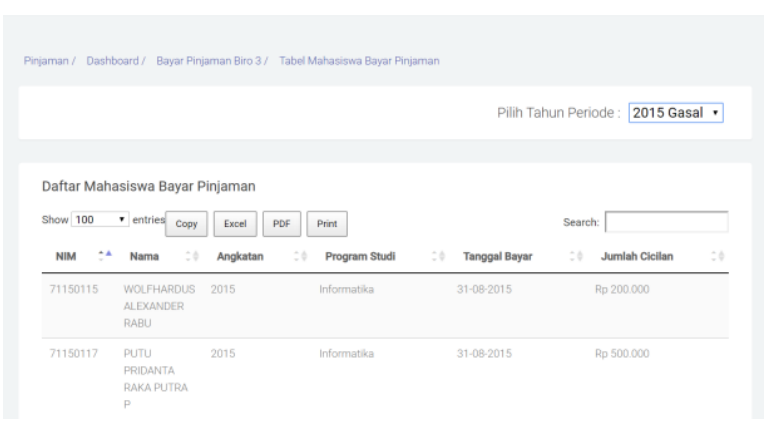

Gambar 28. Tabel bayar pinjaman

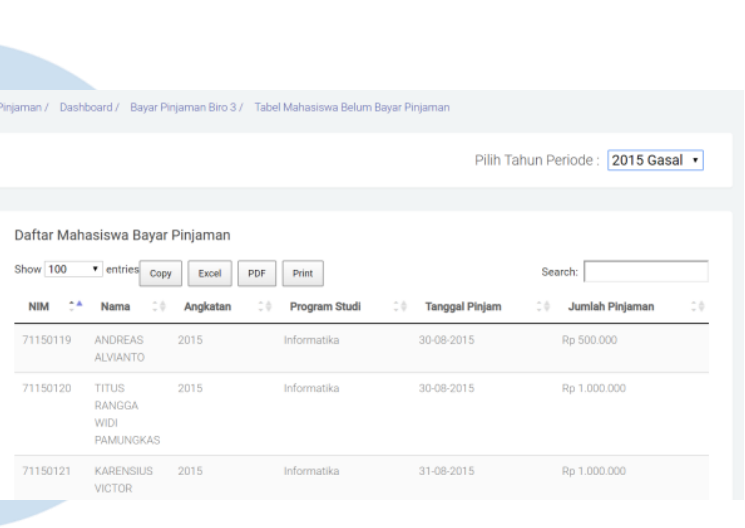

Gambar 29. Tabel belum bayar pinjaman

\section{A.11 Halaman Reporting Pinjaman}

Pilih Tahun Periode: 2015 - hingga: 2016 .

\section{Orang}

Rp. $15,000,000$

Gambar 30. Filter tahun periode dan rekap data pinjaman 


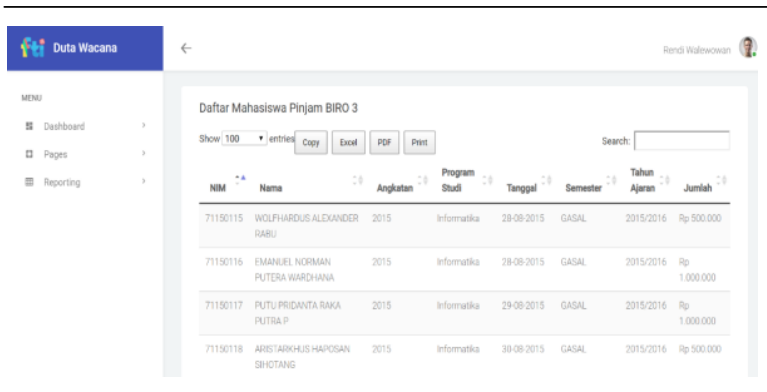

Gambar 31. Tabel reporting pinjaman

Fitur pada halaman reporting pinjaman tidak berbeda dengan halaman reporting beasiswa. Perbedaan pada halaman ini hanya terletak pada isi row tabel yang terdiri dari nim, nama, angkatan, program studi, tanggal pinjam, semester, tahun ajaran dan jumlah pinjaman seperti yang terlihat pada Gambar 31.

\section{B. Evaluasi Sistem Iterasi I}

Tabel 11. Hasil pengujian sistem iterasi I

\begin{tabular}{|c|c|c|c|c|c|c|c|c|c|c|}
\hline & $\begin{array}{c}\text { Ta } \\
s k \\
1\end{array}$ & $\begin{array}{c}T a \\
s k \\
2\end{array}$ & $\begin{array}{c}T a \\
s k \\
3\end{array}$ & $\begin{array}{c}T a \\
s k \\
4\end{array}$ & $\begin{array}{c}T a \\
s k \\
5\end{array}$ & $\begin{array}{c}T a \\
s k \\
6\end{array}$ & $\begin{array}{c}\text { Ta } \\
\text { sk } \\
7\end{array}$ & $\begin{array}{c}T a \\
s k \\
8\end{array}$ & $\begin{array}{c}T a \\
s k \\
g\end{array}$ & $\begin{array}{c}\text { Task } \\
\text { Succ } \\
\text { ess }\end{array}$ \\
\hline Rl & B & B & B & B & B & B & B & B & B & $\begin{array}{c}100 \\
\%\end{array}$ \\
\hline R2 & B & B & B & B & B & $\mathrm{G}$ & B & B & B & $\begin{array}{l}89 \\
\%\end{array}$ \\
\hline R3 & B & B & B & B & B & B & B & B & B & $\begin{array}{c}100 \\
\%\end{array}$ \\
\hline R4 & B & B & B & B & B & B & B & B & B & $\begin{array}{c}100 \\
\%\end{array}$ \\
\hline R5 & B & B & B & B & B & $\mathrm{G}$ & B & B & B & $\begin{array}{l}89 \\
\%\end{array}$ \\
\hline $\begin{array}{c}\text { Tas } \\
\mathbf{k} \\
\text { Succ }\end{array}$ & $\begin{array}{c}10 \\
0 \\
\%\end{array}$ & $\begin{array}{c}10 \\
0 \\
\%\end{array}$ & $\begin{array}{c}10 \\
0 \\
\%\end{array}$ & $\begin{array}{c}10 \\
0 \\
\%\end{array}$ & $\begin{array}{c}10 \\
0 \\
\%\end{array}$ & $\begin{array}{l}60 \\
\%\end{array}$ & $\begin{array}{c}10 \\
0 \\
\%\end{array}$ & $\begin{array}{c}10 \\
0 \\
\%\end{array}$ & $\begin{array}{c}10 \\
0 \\
\%\end{array}$ & $\begin{array}{c}95,5 \\
5 \\
\%\end{array}$ \\
\hline
\end{tabular}

Tabel 11 merupakan hasil pengujian sistem kepada beberapa responden. Pengujian sistem ini dinilai dari berhasil atau tidaknya responden dalam melakukan task yang diberikan. Setiap task yang berhasil akan diberi nilai 1 dan berhasil sebagian diberi nilai 0,5 , sedangkan jika task tersebut gagal akan diberi nilai 0 .

Berdasarkan Tabel 11 terdapat 9 task untuk masing-masing responden, dari hasil yang diperoleh terdapat 1 task yang gagal dikerjakan oleh responden ke-2 dan 5, yaitu pada task 6 dengan nilai $89 \%$ untuk masing-masing responden dan nilai rata-rata task 6, yaitu $60 \%$, hal ini dikarenakan responden sulit menemukan halaman dashboard pinjaman. Dengan demikian diperoleh hasil untuk success rate pada iterasi I adalah 95,55\%.
Tabel 12. Hasil pengujian SUS iterasi I

\begin{tabular}{|c|c|c|c|c|c|c|c|c|c|c|c|c|}
\hline & \multicolumn{10}{|c|}{ Skor Hasil Perhitungan } & \multirow{2}{*}{$\begin{array}{c}\text { Jum } \\
\text { lah } \\
\text { Tota } \\
1\end{array}$} & \multirow{2}{*}{$\begin{array}{c}\text { Nilai } \\
\text { (Jum } \\
\text { lah } \\
\text { Total } \\
\times 2,5 \text { ) }\end{array}$} \\
\hline & $\begin{array}{l}Q \\
1\end{array}$ & $\begin{array}{l}\mathbf{Q} \\
\mathbf{2}\end{array}$ & $\begin{array}{l}\mathbf{Q} \\
\mathbf{3}\end{array}$ & $\begin{array}{l}Q \\
\mathbf{4}\end{array}$ & $\begin{array}{l}Q \\
5\end{array}$ & $\begin{array}{l}Q \\
6\end{array}$ & $\begin{array}{l}\mathbf{Q} \\
7\end{array}$ & $\begin{array}{l}\mathbf{Q} \\
\mathbf{8}\end{array}$ & $\begin{array}{l}Q \\
9\end{array}$ & $\begin{array}{l}\mathrm{Q} \\
\mathbf{1} \\
\mathbf{0}\end{array}$ & & \\
\hline $\begin{array}{l}R \\
1 \\
\end{array}$ & 4 & 4 & 4 & 4 & 4 & 3 & 4 & 4 & 4 & 1 & 36 & 90 \\
\hline $\begin{array}{l}\mathrm{R} \\
2\end{array}$ & 3 & 3 & 3 & 3 & 3 & 3 & 2 & 3 & 3 & 0 & 26 & 65 \\
\hline $\begin{array}{l}R \\
3 \\
\end{array}$ & 3 & 3 & 3 & 4 & 4 & 2 & 3 & 3 & 3 & 4 & 32 & 80 \\
\hline $\begin{array}{l}R \\
4 \\
\end{array}$ & 3 & 3 & 3 & 4 & 2 & 3 & 3 & 3 & 3 & 2 & 29 & 73 \\
\hline $\begin{array}{l} \\
5 \\
\end{array}$ & 3 & 3 & 3 & 1 & 4 & 3 & 3 & 3 & 3 & 1 & 27 & 68 \\
\hline \multicolumn{12}{|c|}{ Rata - rata Nilai SUS } & 75,2 \\
\hline
\end{tabular}

Skor dari masing-masing pertanyaan tersebut didapatkan dari perhitungan dimana hasil dari pertanyaan bernomor genap akan dikurangi dengan 5 dan hasil dari pertanyaan bernomor ganjil akan dikurangi 1.

Pertanyaan Ganjil $=$ [ Hasil Pertanyaan Ganjil -1$]$ Pertanyaan Genap = [5 - Hasil Pertanyaan Genap ]

Skor dari masing-masing pertanyaan setiap responden akan dijumlahkan secara keseluruhan lalu dikalikan dengan 2,5 yang merupakan nilai kali yang berasal dari aturan SUS.

$$
\text { Nilai } S U S=\sum_{x=1}^{10} Q_{x} \times 2,5
$$

Berdasarkan hasil perhitungan, rata-rata nilai SUS pada tabel 12 yaitu 75,2.

\section{Evaluasi Sistem Iterasi II}

Tabel 13. Hasil pengujian sistem iterasi II

\begin{tabular}{|c|c|c|c|c|c|c|c|c|c|c|}
\hline & $\begin{array}{c}T a \\
s k \\
1\end{array}$ & $\begin{array}{c}T a \\
s k \\
2\end{array}$ & $\begin{array}{c}T a \\
s k \\
3\end{array}$ & $\begin{array}{c}T a \\
s k \\
4\end{array}$ & $\begin{array}{c}\text { Ta } \\
s k \\
5\end{array}$ & $\begin{array}{c}T a \\
s k \\
6\end{array}$ & $\begin{array}{c}\text { Ta } \\
\text { sk } \\
7\end{array}$ & $\begin{array}{c}T a \\
s k \\
8\end{array}$ & $\begin{array}{c}T a \\
s k \\
g\end{array}$ & $\begin{array}{c}\text { Tas } \\
k \\
\text { Suc } \\
\text { cess }\end{array}$ \\
\hline Rl & B & B & B & B & B & $\mathrm{G}$ & B & B & B & $\begin{array}{l}89 \\
\% \\
\end{array}$ \\
\hline R2 & B & B & B & B & B & B & B & B & B & $\begin{array}{c}100 \\
\%\end{array}$ \\
\hline R3 & B & B & B & B & B & B & B & B & B & $\begin{array}{c}100 \\
\%\end{array}$ \\
\hline R4 & B & B & B & B & B & B & B & B & B & $\begin{array}{c}100 \\
\%\end{array}$ \\
\hline R5 & B & B & B & B & B & B & B & B & B & $\begin{array}{c}100 \\
\%\end{array}$ \\
\hline $\begin{array}{c}\text { Tas } \\
\mathbf{k}\end{array}$ & 10 & 10 & 10 & 10 & 10 & & 10 & 10 & 10 & $\begin{array}{c}97,7 \\
7\end{array}$ \\
\hline $\begin{array}{l}\text { Suc } \\
\text { cess }\end{array}$ & $\begin{array}{c}0 \\
\%\end{array}$ & $\begin{array}{c}0 \\
\%\end{array}$ & $\begin{array}{c}0 \\
\%\end{array}$ & $\begin{array}{c}0 \\
\%\end{array}$ & $\begin{array}{c}0 \\
\%\end{array}$ & $\begin{array}{l}80 \\
\%\end{array}$ & $\begin{array}{c}0 \\
\%\end{array}$ & $\begin{array}{c}0 \\
\%\end{array}$ & $\begin{array}{c}0 \\
\%\end{array}$ & $\%$ \\
\hline
\end{tabular}

Berdasarkan Tabel 13 terdapat 9 task untuk masing-masing responden, dari hasil yang diperoleh terdapat 1 task yang gagal dikerjakan oleh responden ke-1, yaitu pada task 6 dengan nilai $89 \%$ dan nilai rata-rata task 6 , yaitu $80 \%$, hal ini dikarenakan responden ke-1 juga masih sulit menemukan halaman dashboard pinjaman. Namun, jika dilihat secara 
keseluruhan ada peningkatan pada task 6 sebesar $20 \%$ dari iterasi I dikarekan adanya perubahan pada tampilan mеnи. Dengan demikian diperoleh hasil untuk success rate pada iterasi II adalah 97,77\%.

Tabel 14. Hasil pengujian SUS iterasi II

\begin{tabular}{|c|c|c|c|c|c|c|c|c|c|c|c|c|}
\hline & \multicolumn{10}{|c|}{ Skor Hasil Perhitungan } & \multirow{2}{*}{$\begin{array}{c}\text { Jum } \\
\text { lah } \\
\text { Tota } \\
1\end{array}$} & \multirow{2}{*}{$\begin{array}{c}\text { Nilai } \\
\text { (Jum } \\
\text { lah } \\
\text { Total } \\
\text { x 2,5) }\end{array}$} \\
\hline & $\begin{array}{l}Q \\
1\end{array}$ & $\begin{array}{l}\mathbf{Q} \\
\mathbf{2}\end{array}$ & $\begin{array}{l}\mathbf{Q} \\
3\end{array}$ & $\begin{array}{l}\mathrm{Q} \\
\mathbf{4}\end{array}$ & $\begin{array}{l}\mathbf{Q} \\
5\end{array}$ & $\begin{array}{l}Q \\
6\end{array}$ & $\begin{array}{l}\mathbf{Q} \\
7\end{array}$ & $\begin{array}{l}\mathbf{Q} \\
\mathbf{8}\end{array}$ & $\begin{array}{l}Q \\
9\end{array}$ & $\begin{array}{l}\text { Q } \\
1 \\
0\end{array}$ & & \\
\hline $\begin{array}{l}\mathbf{R} \\
\mathbf{l}\end{array}$ & 3 & 3 & 3 & 1 & 3 & 3 & 3 & 3 & 3 & 1 & 26 & 65 \\
\hline $\begin{array}{l}\mathrm{R} \\
2 \\
\end{array}$ & 4 & 3 & 3 & 4 & 2 & 3 & 2 & 4 & 1 & 4 & 30 & 75 \\
\hline $\begin{array}{l}\mathrm{R} \\
\mathbf{3} \\
\end{array}$ & 4 & 3 & 3 & 4 & 3 & 3 & 3 & 3 & 4 & 3 & 33 & 83 \\
\hline $\begin{array}{l}R \\
4 \\
\end{array}$ & 4 & 4 & 4 & 3 & 3 & 3 & 4 & 4 & 3 & 4 & 36 & 90 \\
\hline $\begin{array}{l}\mathrm{R} \\
5 \\
\end{array}$ & 3 & 3 & 3 & 3 & 3 & 3 & 3 & 3 & 3 & 1 & 28 & 70 \\
\hline & & & & & & & & & & & & 76,6 \\
\hline
\end{tabular}

Berdasarkan hasil perhitungan rata-rata nilai SUS pada tabel 14 yaitu 76,6.

\section{Analisis Antarmuka}

Desain dashboard beasiswa dan pinjaman menerapkan beberapa prinsip desain dalam perancangannya. Berikut beberapa contoh penerapan prinsip desain dalam pembangunan dashboard beasiswa dan pinjaman.

\section{D.1 Proximity}

Dalam perancangan desain dashboard beasiswa maupun pinjaman prinsip proximity selalu digunakan dalam mengatur tata letak konten setiap halaman, baik halaman utama maupun halaman detil dari masingmasing KPI. Berdasarkan tampilan utama dashboard ini dapat dikelompokkan menjadi 5 elemen dasar, yaitu 1 tampilan menu pada sisi kiri, 1 tampilan konten indikator, 1 tampilan untuk filter berdasarkan tahun, 1 tampilan untuk masing-masing KPI, dan 1 tampilan untuk masing-masing chart. Berikut contoh penggunaannya:

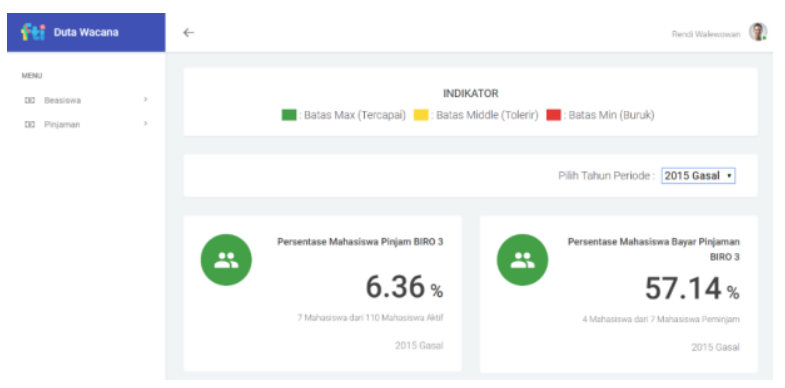

Gambar 32. Proximity pada halaman utama dashboard pinjaman

Sedangkan untuk masing-masing halaman detil, dikelompokkan menjadi 4 elemen, yaitu 1 tampilan menu pada sisi kiri, 1 link navigasi pada sisi kiri atas,
1 tampilan untuk filter berdasarkan tahun, 1 tampilan untuk masing-masing konten, dan 1 tampilan untuk masing-masing chart. Berikut contoh penggunaannya:

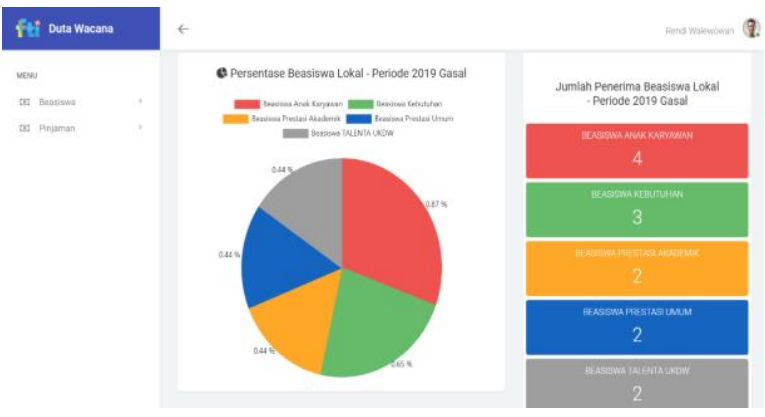

Gambar 33. Proximity pada halaman beasiswa lokal

\section{D.2 Similarity}

Tampilan utama dashboard beasiswa dan pinjaman menggunakan prinsip similarity pada konten KPI dashboard dengan kesamaan bentuk kotak (card) untuk setiap konten KPI-nya. Semua kotak (card) juga menampilkan perilaku yang sama ketika meletakkan mouse (hover) di atas card, hal ini menciptakan pengalaman yang memperkuat prinsip similarity. Berikut beberapa contoh penggunaannya:

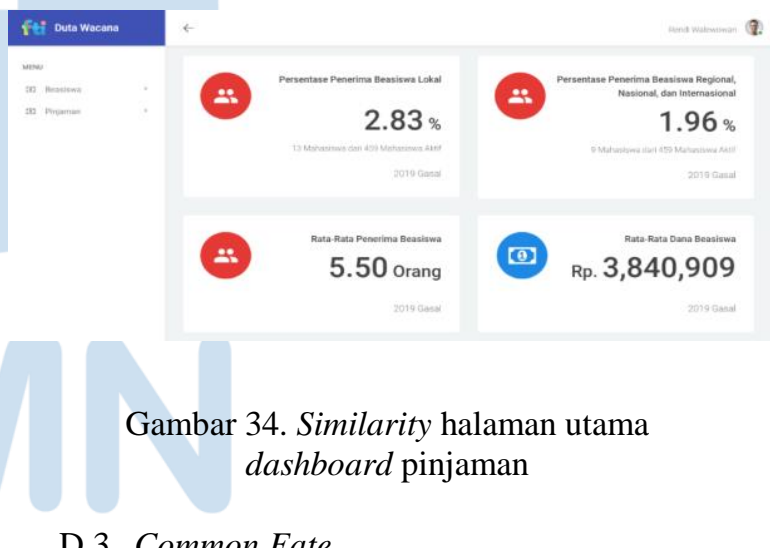

D.3 Common Fate

Prinsip common fate menyatakan bahwa mata manusia cenderung melihat unsur-unsur yang bergerak bersama-sama sebagai suatu kelompok yang lebih mirip satu sama lain daripada unsur yang diam atau bergerak ke arah yang berbeda [15].

Pada dashboard beasiswa dan pinjaman prinsip common fate berlaku pada tampilan menu pada sisi kiri halaman dashboard. Prinsip ini digunakan untuk menghubungkan antara menu dan sub-теnu. 


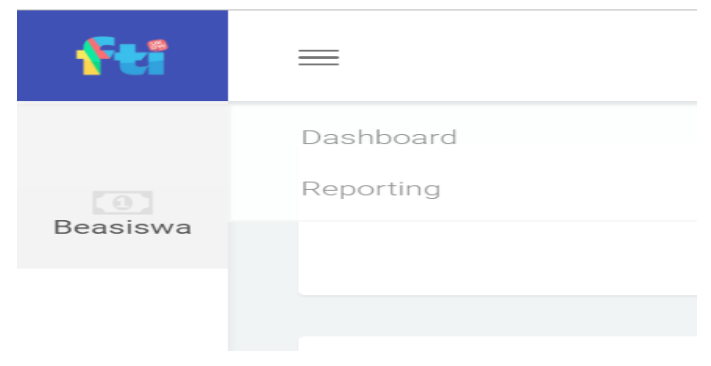

Gambar 35. Common fate pada menu beasiswa

\section{D.4 Focal Point}

Prinsip focal point menyatakan bahwa obyek dengan point of interest akan lebih cepat ditangkap mata dan lebih menarik perhatian karena adanya penekanan atau perbedaan dari unsur obyek lainnya [15].

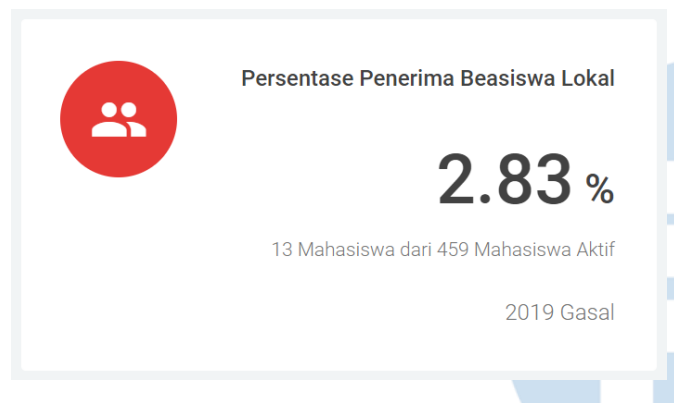

Gambar 36. Focal point pada KPI beasiswa lokal

\section{E. Analisis Pengujian SUS}

Hasil rata-rata nilai SUS pada tabel 12 dan tabel 14 akan diukur menggunakan skala perhitungan SUS, hasil pada pengujian iterasi I menunjukkan SUS skor yang diperoleh adalah 75,2 dan pada iterasi II diperoleh hasil 76,6. Berdasarkan hasil tersebut maka diperoleh rata-rata skor pada kedua iterasi, yaitu 75,9. Dengan demikian, desain iterasi I dan II untuk penilaian acceptability ranges dapat diterima (acceptable). Sedangkan untuk penilaian grade scale hasil pengujian iterasi I dan II mendapat nilai $\mathrm{C}$ dan penilaian adjective ratings pengujian mendapatkan nilai Good. Dengan hasil tersebut, maka usability pada sistem ini dapat dikatakan cukup baik.

\section{F. Analisis Pengujian Task Rate}

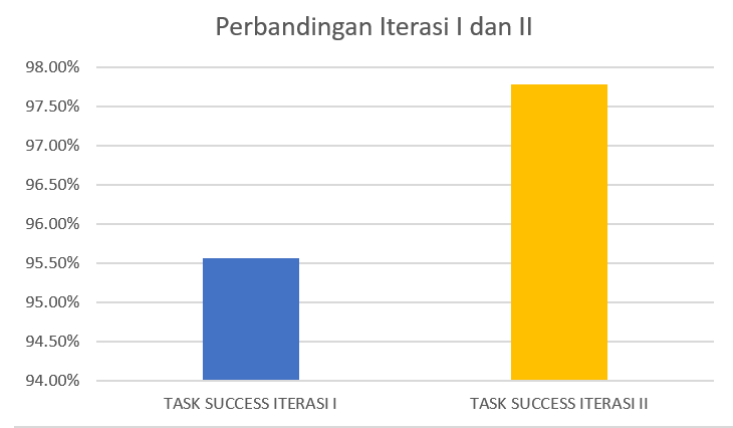

Gambar 37. Perbandingan iterasi I dan II

Gambar 37 menunjukkan adanya perbandingan antara hasil iterasi I dan II. Hasil pada iterasi I menunjukkan pada angka $95,55 \%$ dan iterasi II mengalami peningkatan sebesar $2.22 \%$ sehingga diperoleh hasil $97,77 \%$. Dengan demikian rata-rata task success dari kedua iterasi, yaitu 96, 66\%.

Perbandingan antara iterasi I dan II terletak pada task skenario nomor 6, yaitu "Melihat persentase mahasiswa yang pinjam ke BIRO 3 pada periode 2016 Gasal". Pada task tersebut responden gagal mengerjakan dikarekan default halaman utama dari sistem yang dibangun ketika responden melakukan login, yaitu halaman dashboard beasiswa. Untuk menampilkan persentase mahasiswa pinjam, responden harus masuk ke halaman dashboard pinjaman terlebih dahulu.

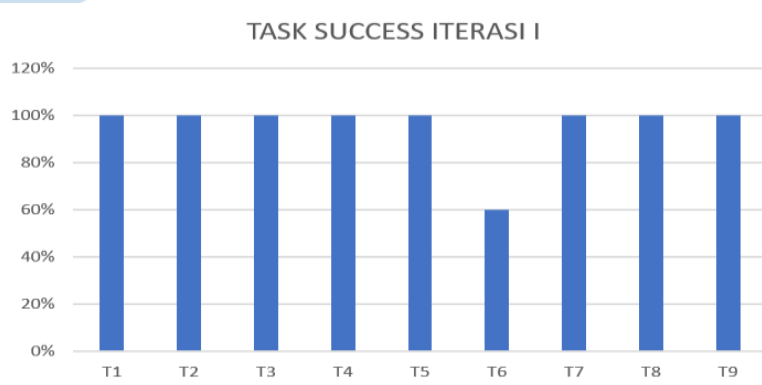

Gambar 38. Task success iterasi I

TASK SUCCESS ITERASI II

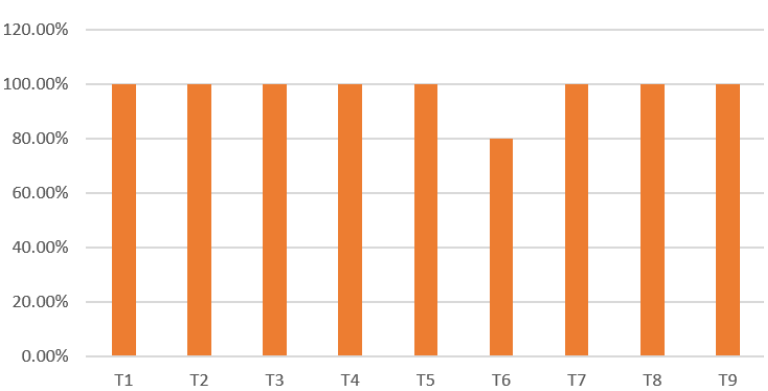

Gambar 39. Task success iterasi II 
Desain тепи pada iterasi I mengharuskan responden masuk melalui menu dashboard dan sub-menu pinjaman seperti pada gambar 40 (kiri). Sedangkan pada iterasi II tampilan menu dan sub-menu memisahkan antara beasiswa dan pinjaman seperti pada gambar 45 (kanan).

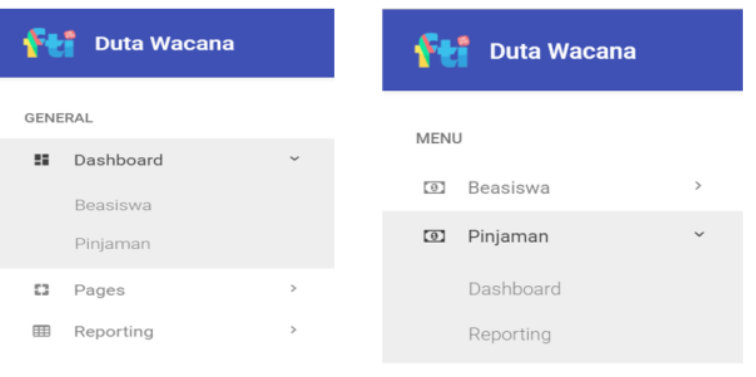

Gambar 40. Menu iterasi I (kiri) dan menu iterasi II (kanan)

Perubahan yang dilakukan pada desain menu tersebut memberikan dampak yang terlihat dari grafik task success iterasi II pada gambar 39. Pada grafik tersebut, task nomor 6 mengalami peningkatan sebesar $20 \%$ pada iterasi II yang sebelumnya pada iterasi I, pada gambar 4.50 bernilai $60 \%$ sedangkan pada iterasi kedua, task nomor 6 menunjukkan nilai $80 \%$. Oleh karena itu pada implementasinya tampilan menu menggunakan tampilan pada iterasi II seperti pada gambar 40 (kanan).

\section{SiMPULAN}

Berdasarkan implementasi, analisis dan pembahasan pada bab-bab sebelumnya, maka dapat ditarik kesimpulan sebagai berikut:

a. Dengan menerapkan metode prototyping maka sistem berhasil dibangun dan memvisualisasikan informasi mengenai beasiswa dan pinjaman ke dalam bentuk dashboard sesuai dengan keinginan user.

b. Hasil rata-rata pengujian task success pada kedua iterasi, yaitu $96,66 \%$ sehingga sistem yang dibangun dapat dikatakan cukup efektif dalam menampilkan informasi beasiswa dan pinjaman serta mudah untuk dipelajari.

c. Evaluasi desain antarmuka yang dilakukan menggunakan System Usability Scale (SUS) menunjukkan skor SUS 75,2 pada iterasi I dan 76,6 pada iterasi II. Berdasarkan hasil tersebut diperoleh rata-rata skor SUS untuk kedua iterasi, yaitu 75,9. Dengan demikian, antarmuka sistem dinyatakan cukup baik dengan grade scale bernilai C, adjective rating bernilai Good, dan acceptability ranges dapat diterima (acceptable).

\section{DAFTAR PUSTAKA}

[1] P. M. Ogedebe and B. . P. Jacob, "Software Prototyping: A Strategy to Use When User Lacks Data Processing Experience," ARPN Journal of Systems and Software , pp. 219-224, 2012.

[2] R. K. Putra, "Apa itu Dashboard ?," 7 Januari 2018. [Online]. Available: https://timur.ilearning.me/2018/01/07/apa-itudashboard/.

[3] F. C. Saputro, W. Anggraeni and A. Mukhlason, "Pembuatan Dashboard Berbasis Web Sebagai Sarana Evaluasi Diri Berkala untuk Persiapan Penilaian Akreditasi Berdasarkan Standar Badan Akreditasi Nasional Perguruan Tinggi," JURNAL TEKNIK ITS, pp. 2301 - 9271, 2012.

[4] B. Dashboard, "Business Intelligence, Data visualization, KPI," BI Dashboards, [Online]. Available: https://www.bidashboard.org/types/tactical.html. [Accessed 30 May 2020].

[5] A. Susanto and M., "System Development Method with The Prototype Method," INTERNATIONAL JOURNAL OF SCIENTIFIC \& TECHNOLOGY RESEARCH, vol. 8, no. 7, pp. 141-144, 2019.

[6] J. Nielsen, "Nielsen Norman Group," 3 Januari 2012. [Online]. Available: https://www.nngroup.com/articles/usability-101-introductionto-usability/.

[7] M. Soegaard, "Interaction Design Foundation," 13 September 2019. [Online]. Available: https://www.interactiondesign.org/.

[8] R. W. Putra and B. Muhdaliha, "Analisis Visual Game Arena Of Valor Sebagai Dasar Pengembangan Konsep Visual Game," Jurnal Avant Garde V, pp. 98-113, 2017.

[9] "Temukan Pengertian," 2014. [Online]. Available: https://www.temukanpengertian.com/2014/03/pengertianreporting.html.

[10] M. Y. Alfiqie, I. Aknuranda and N. H. Wardani, "Evaluasi Usability Pada Aplikasi UBER Menggunakan Pengujian Usability," Jurnal Pengembangan Teknologi Informasi dan Ilmu Komputer, pp. 2599-2606, 2018.

[11] J. Sauro, "MEASURING USABILITY WITH THE SYSTEM USABILITY SCALE (SUS)," 2 February 2011. [Online]. Available: https://measuringu.com/sus/.

[12] B. Kho, "Pengertian KPI (Key Performance Indicator) atau Indikator Kinerja Utama," 24 Mei 2018. [Online]. Available: https://ilmumanajemenindustri.com/pengertian-kpi-keyperformance-indicators-indikator-kinerja-utama/.

[13] H. and E. Winarko, "Rancangan Sistem Data Warehouse Evaluasi Kinerja," Seminar Nasional Teknologi Informasi dan Multimedia, pp. 13-18, 2015.

[14] R. Kimball, M. Ross, W. Thornthwaite, J. Mundy and B. Becker, The Data Warehouse Lifecycle Toolkit, Indianapolis: Wiley Publishing, Inc, 2008.

[15] R. W. Anggoro, 23 September 2016. [Online]. Available: https://www.niagahoster.co.id/blog/website-profesionalgestalt/. 